\title{
EDITORIAL
}

\section{A quem cabe competência para organizar congressos científicos?}

$O$ "2nd World Congress of Cellular and Molecular Biology", realizado em Ottawa (Canadá), de 3 a 6 de setembro pp, sucedeu o "1st World Congress of Cellular and Molecular Biology", realizado em Paris, em 1991. Devem-se a iniciativa do Professor Raymond Wegmam, "Editor-in-Chief" do periódico Cellular and Molecular Biology (CMB), editado em Paris. No primeiro congresso, foi fundada a World Society of Cellular and Molecular Biology (WSCMB), com a adesão de participantes do congresso e dos membros do "Editorial Board" daquele periódico. A WSCMB organizou o atual congresso com o patrocínio do "Medical Research Council" do Canadá. Presidiu o Comitê Científico, J.E. Trosko (Michigan State University), e o Comitê Organizador Canadense, M.M. Ennaji (National Research Council - Montreal), co-presidente do Comitê Científico. Participavam do Comitê Internacional os já citados, mais R.F. Ochillo (Xavier University - Louisiana), J.A. Grimaud (Institut Pasteur - Lyon), K.J. Halbhuber (Universitat Friedrich Schiller - Iena), S.A. McNairy (National Institut of Health - Bethesda) e T. Nagata (School of Medicine, Shinshu University - Matsumoto), além do Professor Wegmann (Institut d'Histochimie Médicale des Universités de Paris).

Com a aproximação da data, pôde-se perceber que alguma coisa não andava bem. $O$ congresso, previsto para o período de 1 a 7 de setembro, foi encurtado para quatro dias. Os participantes, surpreenderam-se com o número reduzido de cerca de duas centenas de inscritos e com os tropeços da organização, inimaginável em um país com a infra-estrutura do Canadá. Souberam, estarrecidos, que tudo se passava em decorrência de atos perpetrados em nome da "The Canadian Society of Biochemistry and Molecular \& Cellular Biology" (CSBMCB), pelo seu presidente Peter J. Dolphin, e pela revista "Biochemistry and Cell Biology", através de seu co-editor David L. Brown. Divulgou-se que o primeiro desses senhores fez uma circular aos departamentos canadenses de Bioquímica, Biologia e Biologia Celular, proscrevendo o "2nd World Congress of Cellular and Molecular Biology" $e$ conclamando os associados da CSBMCB a não se inscreverem, mas, reservarem seus trabaIhos para congresso similar, a ser realizado em dezembro, organizado pela Federação Internacional de Biologistas Celulares. O segundo, aos 19/11/1995, escreveu à Diretora da "NRC Press", solicitando-lhe que periódicos ligados a NRC não anunciassem o "2nd World CMB Congress". Em sua carta, sugere que a "Internacional Federation for Cell Biology" (IFCB) é a organização legítima para patrocinar um evento da envergadura pretendida pela WSCMB, ficando este relegado a uma casta de desconhecidos. Em resumo, esses senhores, valendo-se de posições em respeitáveis instituições científicas, tomaram iniciativa de ética discutível, ao combaterem direitos inalienáveis, quais sejam os do livre direito de reunião e de associação. 
O congresso patrocinado pela WSCMB e organizado por um comitê de pessoas competentes em suas áreas de atuação, sem vedetismo, tem a particularidade de não estimular a apresentação de "posters"; essa forma de apresentação de trabalhos, tão difundida nos grandes congressos atuais, tem vantagens e desvantagens; o grande número de congressistas cria, com o "poster", uma feira de ciências, mas impede o autor de se expor à platéia, falando e discutindo de público o seu trabalho. Tal atitude heterodoxa nos congressos da WSCMB tem sua contrapartida na filosofia da revista CMB, que procura se abrir à produção científica, de qualquer parte do mundo, com "peer review", sem exigir dos autores a transferência de direitos autorais, por considerá-la uma apropriação indébita do trabalho intelectual do cientista. Ou seja, a WSCMB tem suas próprias normas. Não se pode contestar o peso de uma federação de associações e parecerá presunçosa qualquer associação independente, que pretenda organizar um congresso de abrangência mundial. Todavia, pode-se reconhecer a qualquer associação ou federação de associações a competência para monopolizar congressos científicos? O episódio expõe os aspectos éticos relacionados, como direito de livre reunião e manifestação em ciência. São direitos especialmente sagrados para os profissionais ligados à pesquisa e à Universidade. Eles se educam com visão crítica dos fatos, testam suas incertezas na investigação científica, divulgam suas conclusões através de artigos escritos em periódicos rigorosamente conduzidos, ou em congressos, onde se associam livremente e, reunidos, podem se manifestar e trocar idéias, dentro dos melhores preceitos do comportamento ético-moral e social. O debate, que há alguns anos chegou à imprensa leiga, sobre os aspectos éticos envolvidos na pesquisa em engenharia genética, não se deveu à ação de associações controladoras dos caminhos da ciência. Decorreu, sim, da ação dos cientistas envolvidos, com noção exata dos aspectos éticos inerentes. Não houvesse a liberdade de expressão científica, e estaríamos ainda aferrados ao conceito da geração espontânea. A História ensina-nos como é revoltante, que quaisquer grupos, políticos ou científicos, proclamem o monopólio do direito de reunião e de expressão, usando métodos, como os mencionados. As Sociedades fundadas no Direito dispensam tais hegemonias. Rui Barbosa já ensinava que essas condutas terminam por suprimir o Direito pela Força. Imagine-se o que não fariam os indivíduos que procuram abafar direitos, valendo-se desses subterfúgios, se pudessem dispor da força que tantas vezes já esmagou aqueles.

A figura do deus mitológico, Janus, representado com duas faces, voltadas para a frente e para trás, foi o tema da conferência de abertura do congresso de Ottawa, pronunciada pelo Prof. Leo Esaki, Prêmio Nobel de Física de 1973, que explorou o dualismo em fenômenos físicos e biológicos. A metáfora aplica-se inteiramente àqueles que sabotaram o congresso. Certamente almejam progressos, mas perdem-se na faceta conservadora e inaceitável, ainda vigente neste século, dos que teimam em controlar o ambiente e tutelar os atos individuais. Conseguiram reduzir o número de participantes e encurtar o evento, mas não impediram a sua realização. Que os julgue a comunidade científica internacional $e$ sejam esses atos execrados pela História.

Prof.Dr. JOSÉ ALBERTO MELLO DE OLIVEIRA Professor Titular de Patologia 